PNL-6976

UC-511

$\therefore P$

\title{
324 and 325 Building \\ Hot Cell Cleanout Program \\ Decontamination of C-Cell
}

Y. B. Katayama

L. K. Holton, Jr.

October 1989

Prepared for the U.S. Department of Energy under Contract DE-AC06-76RLO 1830

Pacific Northwest Laboratory

Operated for the U.S. Department of Energy

by Battelle Memorial Institute 


\title{
DISCLAIMER
}

This program was prepared as an account of work sponsored by an agency of the United States Government. Neither the United States Government nor any agency thereof, nor Battelle Memorial Institute, nor any or their employees, makes any warranty, expressed or implied, or assumes any legal liability or responsibility for the accuracy, completeness, or usefulness of any information, apparatus, product, or process disclosed, or represents that its use would not infringe privately owned rights. Reference herein to any specific commercial product, process, or service by trade name, trademark. manufacturer, or otherwise, does not necessarily constitute or imply its endorsement, recommendation, or favoring by the United States Covernment of any agency thereof, or Battelle Memorial Institute. The views and opinions of authors expressed herein do not necessarily state or reflect those of the United States Government or any agency thereof.

\author{
PACIFIC NORTHWEST LABORATORY \\ operated by \\ BATTELLE MEMORIAL INSTITUTE \\ for the \\ UNITED STATES DEPARTMENT OF ENERGY \\ under Contract DE-ACO6-76RLO 1830
}

Printed in the United States of America

Available to DOE and DOE contractors from the

Office of Scientific and Technical Information, P.O. Box 62, Oak Ridge, TN 37831; prices available from (615) 576-8401. FTS 626-8401.

Available to the public from the National Technical information Service, U.S. Department of Commerce, 5285 Port Royal Rd., Springfield, VA 22161.

NTIS Price Codes, Microfiche A01

Printed Copy

\begin{tabular}{cc}
$\frac{P}{\text { Pages }}$ & $\begin{array}{c}\text { Price } \\
\text { Codes }\end{array}$ \\
\hline $007-025$ & A02 \\
$026-050$ & A03 \\
$051-075$ & A04 \\
$076-100$ & A05 \\
$101-125$ & A06 \\
$126-150$ & A07 \\
$151-175$ & A08 \\
$176-200$ & A09 \\
$201-225$ & A10 \\
$226-250$ & A11 \\
$251-275$ & A12 \\
$276-300$ & A13
\end{tabular}


324 AND 325 BUILDING

HOT CELL CLEANOUT PROGRAM

DECONTAMINATION OF C-CELL

Y. B. Katayama

L. K. Holton, Jr.

October 1989

Prepared for

the U.S. Department of Energy

under Contract DE-AC06-76RLO 1830

Pacific Northwest Laboratory

Richland, Washington 99352 


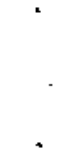




\section{SUMMARY}

During FY 1989 the decontamination of C-Ce1T of Hanford's 324 Building was completed as part of the 324 and 325 Building Hot Ce1l Cleanout Program sponsored by the DOE Nuclear Energy's Surplus Facilities Management Program. The decontamination effort was completed using a series of remote and contact decontamination techniques. Initial radiation readings in $\mathrm{C}-\mathrm{Ce} \mathrm{Tl}$ averaged $50 \mathrm{rad} / \mathrm{hr}$ and were reduced remotely to less than $200 \mathrm{mrad} / \mathrm{hr}$ using an alkaline foam cleaner followed by a 5000-psi water flush. Contact decontamination was then permissible using ultra high-pressure water, at 36,000 psi, further reducing the average radiation level in the cell to less than $86 \mathrm{mrem} / \mathrm{hr}$.

The approach used in decontaminating $\mathrm{C}-\mathrm{C}$ - 11 resulted in a savings in radiation exposure of $87 \%$ and a cost savings of $39 \%$ compared to a hands-on procedure used in A-Ce11, 324 Building in 1987. The radiation dose and the costs to achieve a 244-fold reduction in radiation contamination were 1.65 mrem per $\mathrm{ft}^{2}$ and $\$ 96$ per $\mathrm{ft}^{2}$ of cell surface area. 


\section{ACKNOWLEDGMENTS}

Successful completion of the final decontamination of $\mathrm{C}$-Cell resulted from team effort. This team consisted of Galen Buck, Jim Hutchens, Mark Culverhouse, Steve Halstead, Sam Morris, John Rau, Ed Doan, Jerry Duce, Ron Holeman, Jim Dunn, Jim Gose, and Frank Haun of the Process Application Section; Frank Gonzales and Jim Helms of Radiation Protection; and Terry Mohar, Mel Owen, Gene Robles, Dennis Smith, Jack Griffith, and Randy Odd of Engineering and Craft Services. 


\section{CONTENTS}

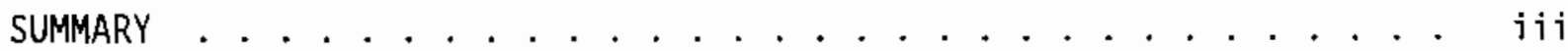

ACKNOWLEDGMENTS . . . . . . . . . . . . . . . . . . . . jv

INTRODUCTION . . . . . . . . . . . . . . . . . . . . . . . . 1

STATUS OF CELL BEFORE DECONTAMINATION . . . . . . . . . . . . . . 2

CELL DECONTAMINATION . . . . . . . . . . . . . . . . . . . . . 6

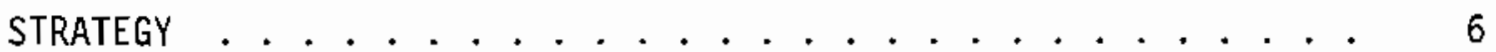

REMOTE PRELIMINARY DECONTAMINATION . . . . . . . . . . . 6

FINAL DECONTAMINATION . . . . . . . . . . . . . . . 14

POST-DECONTAMINATION ANALYSES . . . . . . . . . . . . . . . 21

CONCLUSIONS . . . . . . . . . . . . . . . . . . . . . 24 



\section{FIGURES}

1324 Building Radiochemical Engineering Cells . . . . . . . . 2

2 Measurements in $\mathrm{rad} / \mathrm{hr}$ (beta + gamma) of $\mathrm{C}-\mathrm{Cell}$

Contamination..................... 3

3 C-Cell Smearable Contamination Sampling Areas . . . . . . . . . . 4

4 Alkaline Foam Being Sprayed onto C-Cell Wa1l . . . . . . . . 7

$5 \quad$ Alkaline Foam, After About a 30-min. Soak, Being Washed from $\mathrm{C}$-Cell Wall with Pressurized Water . . . . . . . . . 8

6 Articulated Spray Wand Suspended on Cell Crane . . . . . . . . 9

7 View Through C-Cell Viewing Periscope Showing Debris Washed to Trough During First Decontamination Cycle . . . . . . . . 10

8 Numerical Designations, as used in Table 3, for Areas in the $6 \times 8$ Radiation Survey Matrix and for the Six Additional Remotely Surveyed Areas . . . . . . . . . . . . . 14

9 Training Session on Use of Admac Jetlance with 36-in. Extension................ . . 16

10 Demonstration of Potential Hazards Resulting from Careless Use of Jetlance . . . . . . . . . . . . . 17

11 View of Operation When U1tra High-Pressure Water Is Initially Turned on in Jetlance . . . . . . . . . . . . 18

12 Typical Distance Between Jetlance and Surface During Decontamination ................. . 19

13 Physical Conditions for Elevated Hand-Held Jetlance Operation . . 20

14 Locations of Final Radiation Survey in C-Cell Shown on a Floor and Wall Layout Sketch . . . . . . . . . . . . . . . . 


\section{TABLES}

1 Radiochemistry of Five Surface Areas in C-Cell After Vacuum Cleaning ................ 5

2 Ratio of Activity Level of Radionuclide to Activity Level of ${ }^{244} \mathrm{Cm} \ldots \ldots . . . \ldots 5$

3 Radiation Data Taken During Preliminary Remote Decontamination of C-Cell, in rads/hr, and Calculated Decontamination Factors . . 12

4 Final Radiation Survey Measurements in C-Cel1 ........ 22 


\section{DECONTAMINATION OF C-CELL}

\section{INTRODUCTION}

C-Ce11, a component of the 324 Building Radiochemical Engineering Facilities at the Pacific Northwest Laboratory (PNL), (a) is one of the six hot cells designated for cleanout in the 324 and 325 Building Hot Cell Cleanout Program. This program is funded primarily by the Department of Energy's (DOE) Nuclear Energy-managed Surplus Facilities Management Program, with support from other DOE organizations. C-Cell, in service since the mid 1960s, has been used mainly for completing characterization studies of nuclear waste forms. Durability testing of spent fuels and high-level waste (HLW)-filled borosilicate glasses comprised the primary long-term studies completed in C-Cell. Shorter duration activities have most recently included the preparation of ${ }^{137}$ Cs irradiation capsules for a Federal Republic of Germany commercial sewage plant, the thermal cycling of a WESF(b) ${ }^{137} \mathrm{Cs}$ capsule, the recovery of noble metals from calcined HLW, and service as the support facility for analyzing samples from vitrification processing runs in $\mathrm{B}-\mathrm{Ce}$ ll, 324 Building.

All these activities had led to an accumulation of surplus in-cell equipment and materials that needed to be cleaned from $\mathrm{C}-\mathrm{Cell}$ to allow further use of the facility. Major portions of the resultant waste from these programs were removed remotely and placed into burial boxes for disposal. Cell decontamination, however, was needed to allow manned entries to remove residual attached material that could not readily be removed remotely.

This report describes the decontamination of $\mathrm{C}-\mathrm{C}$-11, and details are provided with the expectation that they may be helpful at other sites doing decontamination work.
(a) Operated for the U.S. Department of Energy by Battelle Memorial Institute under Contract DE-AC06-76RLO 1830.
(b) Waste Encapsulation and Solidification Facility. 


\section{STATUS OF CELL BEFORE DECONTAMINATION}

C-Cell is located beneath D-Cell, and these two half-height cells form the southern arm of the Radiochemical Engineering Facility as shown in Figure 1. All four cells are connected through the centrally located air lock. C-Ce11 measures $12 \mathrm{ft}$ wide by $19.4 \mathrm{ft}$ long by $15 \mathrm{ft}$ high and has two oil-filled leaded glass viewing windows along its length, with a pair of manipulators at each window. Normally these manipulators are the $10-\mathrm{ft}$ Model $E$ type, but for the cell cleanout a heavier duty 10-ft Model $F$ manipulator was substituted for the right-hand position of the west viewing window. In addition to the four cell penetrations for the manipulators, there are 14 4-in.-dia penetrations to the operating gallery and one 4-in. penetration to the cask-handling area, at the east wall of the cell. One of the 4-in. penetrations to the operating gallery is used as a transfer port. There are a transfer tray and a cell door connecting the air lock to the cell, and

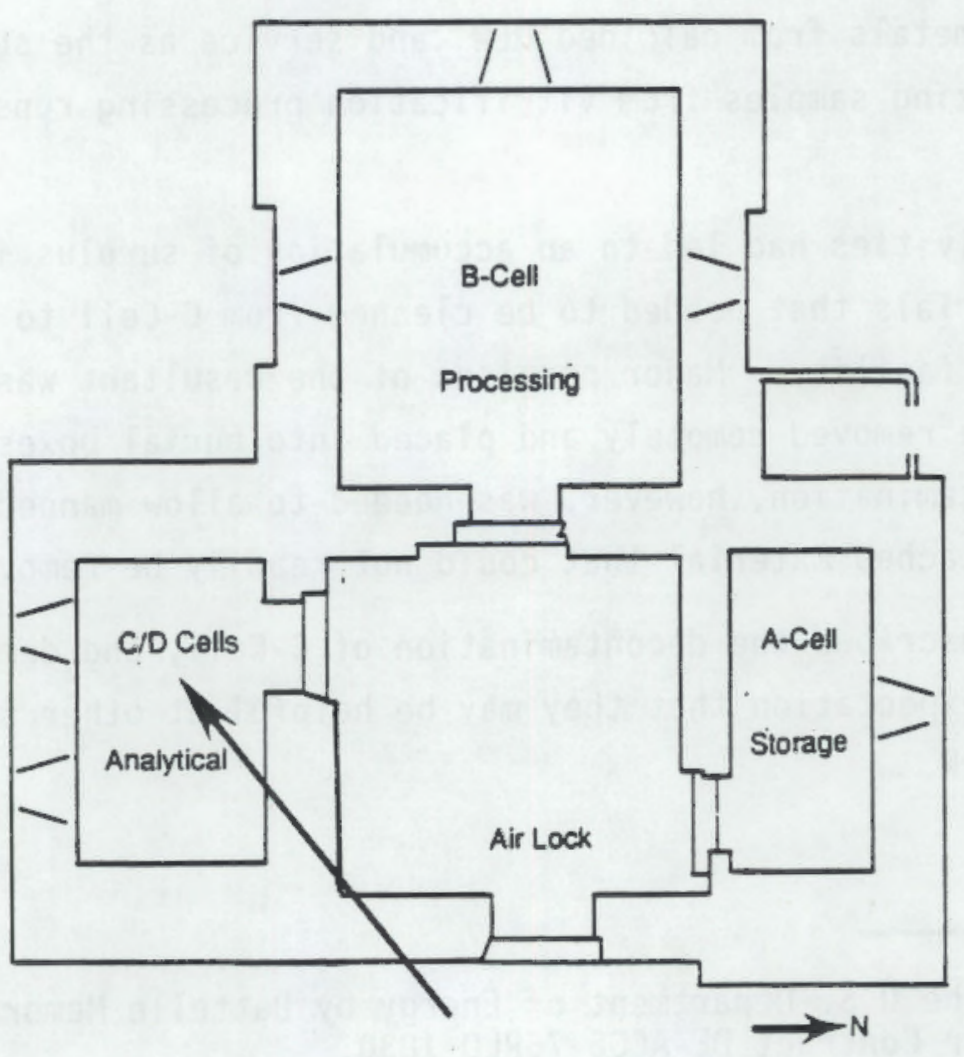

FIGURE 1. 324 Building Radiochemical Engineering Cells 
there is a stepped plug in the ceiling of the cell which is removable from D-Cel1. Al1 surfaces of the cell are lined with 11-gage stainless steel that has all seams welded. The lining in the sump is suspected to have a leak, the leaded glass shielding windows have become damaged over 21 years of use, and the cell captive overhead crane is in need of contact maintenance.

After most of the surplus in-cell materials were removed, the cell floor was swept remotely with a broom and dustpan to remove the large debris, vacuumed to remove the smaller particulates, and then surveyed remotely with an in-cell Eberline $\mathrm{ROF}^{(\mathrm{a})}$ medium-range radiation detection system. To monitor progress of cell decontamination, the floor area was divided into a 6 by 8 matrix and radiation exposure was periodically measured centrally in each $-2-\mathrm{ft}^{2}$ matrix area. Any localized hot spots found were noted on the radiation survey sheets. Measurement results from the first survey following a floor sweep and vacuum are shown in figure 2 . The radiation rate ranged

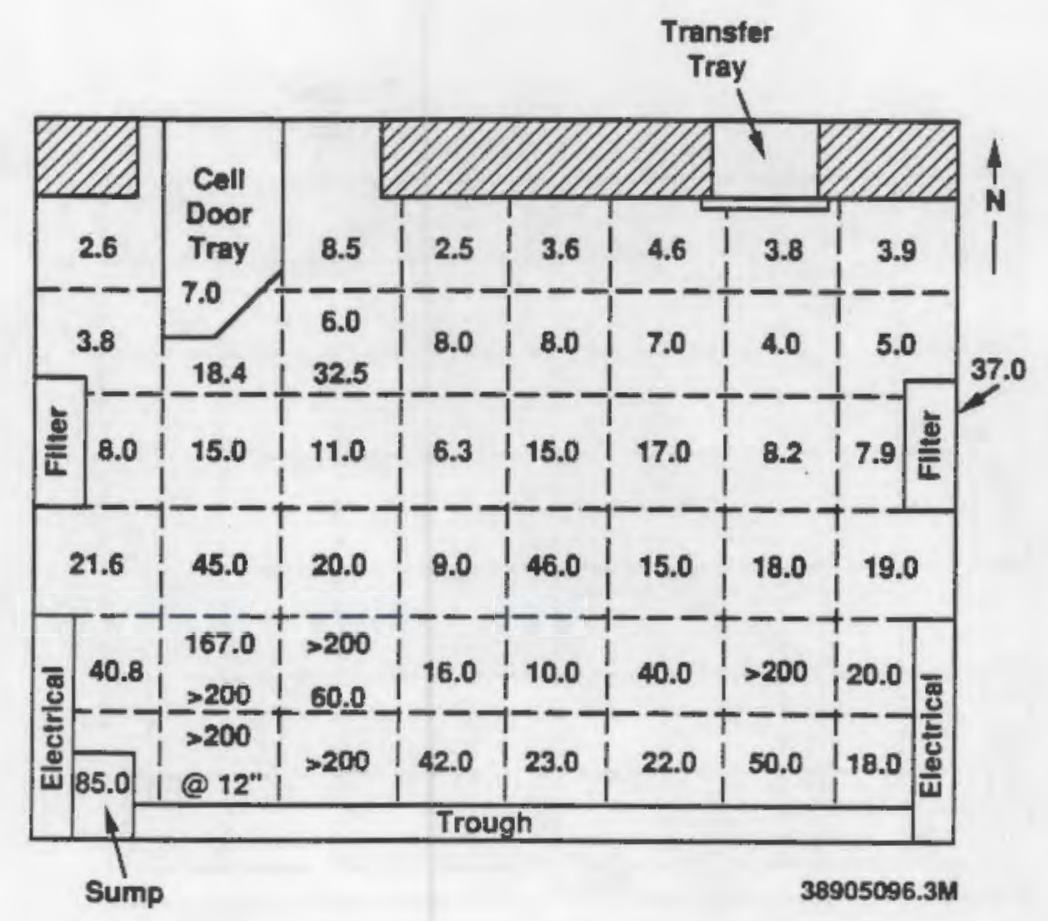

FIGURE 2. Measurements in $\mathrm{rad} / \mathrm{hr}$ (beta + gamma) of C-Cell Contamination

(a) Manufactured by the ThermoElectron Corporation, Sante Fe, New Mexico. 
from 2.6 to $>200 \mathrm{rad} / \mathrm{hr}$, the maximum 1 imit of the medium-range radiation probe used. High radiation levels correlate with the locations of in-cell work table areas, in front of the shielded viewing windows, where most of the manipulator-handled activities had been performed. The transfer of B-Cell processing samples into $\mathrm{C}-\mathrm{C}$ lll via the shelf on the cell door may account for the areas of increased radiation extending from the door shelf to the work tables.

Smear samples of selected areas measuring about $100 \mathrm{~cm}^{2}$ were taken remotely on cotton dental rolls wetted with $2 \mathrm{M} \mathrm{HNO}_{3}$, and then packaged and shipped to the Radiochemistry Laboratory for analyses. The areas that were smear-sampled are shown as circled numbers in Figure 3 . These numbers serve to locate the smear samples enumerated in Tables 1 and 2 as follows: Smear no. 1 was taken from a hot spot in the trough; no. 2 from the top surface of the electrical service rack on the west wal1; no. 3 from a hot spot in front of the east window; no. 4 from a generally low-level area near the north

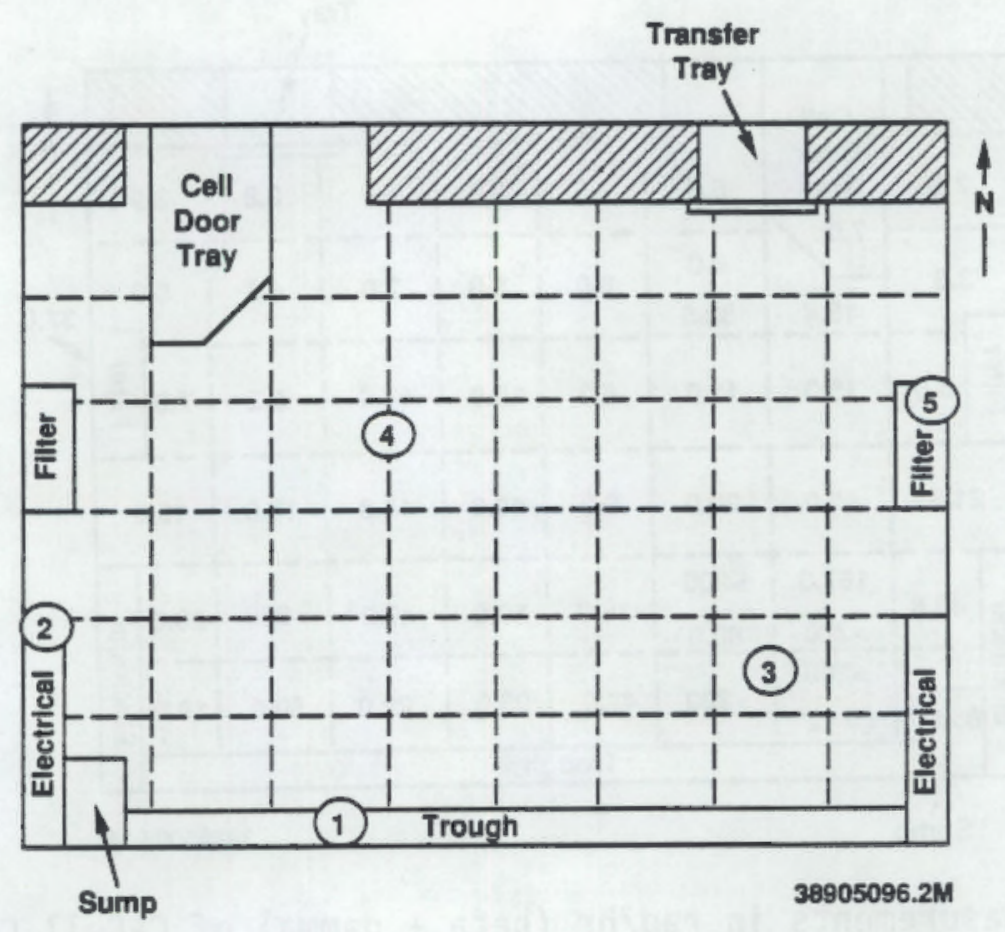

FIGURE 3. C-Cell Smearable Contamination Sampling Areas 
TABLE 1. Radiochemistry of Five Surface Areas in C-Cell After Vacuum Cleaning

\begin{tabular}{|c|c|c|c|c|}
\hline \multicolumn{5}{|c|}{$\frac{\text { Smear Samples }-100 \mathrm{~cm}^{2}}{\text { dis } / \mathrm{min} / \mathrm{smear}}$} \\
\hline 1 & 2 & 3 & 4 & 5 \\
\hline $2.21 E 6$ &.- & $3.72 \mathrm{E} 6$ & -- & 1.19E6 \\
\hline $5.84 \mathrm{ES}$ & $2.22 \mathrm{E} 9$ & $3.21 \mathrm{Eg}$ & $2.92 \mathrm{Eg}$ & $5.08 \mathrm{~EB}$ \\
\hline $1.78 \mathrm{E} 6$ & $\cdots$ & $\cdots$ & -- & $\cdots$ \\
\hline $3.98 E 9$ & $8.75 \mathrm{E} 9$ & 1.39E9 & 2.84E9 & $4.32 \mathrm{E} 8$ \\
\hline $1.36 \mathrm{E} 5$ & $6.41 E 4$ & $1.51 E 5$ & $7.08 \mathrm{E} 4$ & $4.66 \mathrm{E} 4$ \\
\hline $1.47 \mathrm{E} 6$ & $5.93 \mathrm{E} 5$ & $2.15 \mathrm{E} 6$ & $9.09 \mathrm{E} 5$ & $5.28 \mathrm{E} 5$ \\
\hline $1.76 \mathrm{E} 6$ & $8.91 \mathrm{E} 5$ & 3.19E6 & $1.40 \mathrm{E} 6$ & $7.05 \mathrm{E} 5$ \\
\hline & & $\mu \mathrm{g} / \mathrm{sme}$ & & \\
\hline 33 & 15 & 83 & 15 & 15 \\
\hline
\end{tabular}

TABLE 2. Ratio of Activity Level of Radionuclide
to Activity Level of $244 \mathrm{Cm}$ Smear Samples

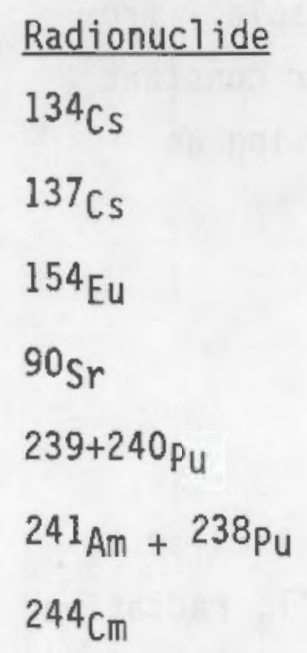

U 
wall; and no. 5 from the top surface of the east exhaust filter housing. Results of the radiochemical analyses given in Table 1 show the presence of spent fuel along with indications of contaminating contributions from experiments using ${ }^{137} \mathrm{Cs}$ and ${ }^{90} \mathrm{Sr}$. This indication becomes clearer when the analytical data are ratioed to ${ }^{244} \mathrm{Cm}$, which was present in C-Cell solely from spent fuel, as shown in Table 2. The actinide elements are near constant whereas the cesium and strontium ratios are more varied, indicating an increase from sources other than spent fuel.

\section{CELL DECONTAMINATION}

\section{$\underline{\text { STRATEGY }}$}

The radiation levels in $\mathrm{C}-\mathrm{Ce}$ ll before decontamination were similar to those in A-Cell before it was decontaminated in 1987. For A-Cell, radiation exposures totalled about 33,000 mrem and the cost of decontamination totalled about $\$ 420,000$. Although these numbers were expected to be lower for $\mathrm{C}-\mathrm{Ce} 11$ since the surface area there is $59 \%$ that of $\mathrm{A}-\mathrm{Ce} 11$, the extrapolated numbers of 20,000 mrem and $\$ 250,000$ were still considered inappropriately high. Since the major contributor to these large numbers had been the use of an essentially total hands-on decontamination process, it was decided to maximize the use of remote and/or technically advanced processes. For $\mathrm{C}-\mathrm{Ce} 11$, the choice was remote soak/pressurized water-rinse to a radiation level of about $200 \mathrm{mrad} / \mathrm{hr}$ or lower before manned entry for final decontamination with ultra high-pressure water. The soak/pressurized water rinse had effectively removed smearable contamination during a decontamination demonstration in July 1988 on the air lock cover blocks.

\section{REMOTE PRELIMINARY DECONTAMINATION}

The preliminary decontamination was done remotely by combining an alkaline cleaner foam spray system with a pressurized water system. A decontamination cycle included loosening the adhering surface contaminants with a foam soak followed by a pressurized water rinse. 
The foam spray was applied through an ARO(a) low-pressure, double-acting piston air pump with a $1: 1$ compression ratio, which 1 imited the foam spray to the building air supply of about $100 \mathrm{psig.} \mathrm{The} \mathrm{chemical} \mathrm{composition} \mathrm{of} \mathrm{the}$ foam was determined during the initial equipment setup and consists of one part AE-3003 alkaline jet engine cleaner, two parts FOME ADD foam stabilizer, and ten parts water. Both additives are proprietary formulations of DuBois Chemical(b). At $100 \mathrm{psig}$ the pump flow rate is about $3 \mathrm{gpm}$ and the maximum nozzle-to-surface working distance is about $12 \mathrm{ft}$. Figure 4 shows alkaline foam being sprayed on the $\mathrm{C}-\mathrm{Cell}$ wall.

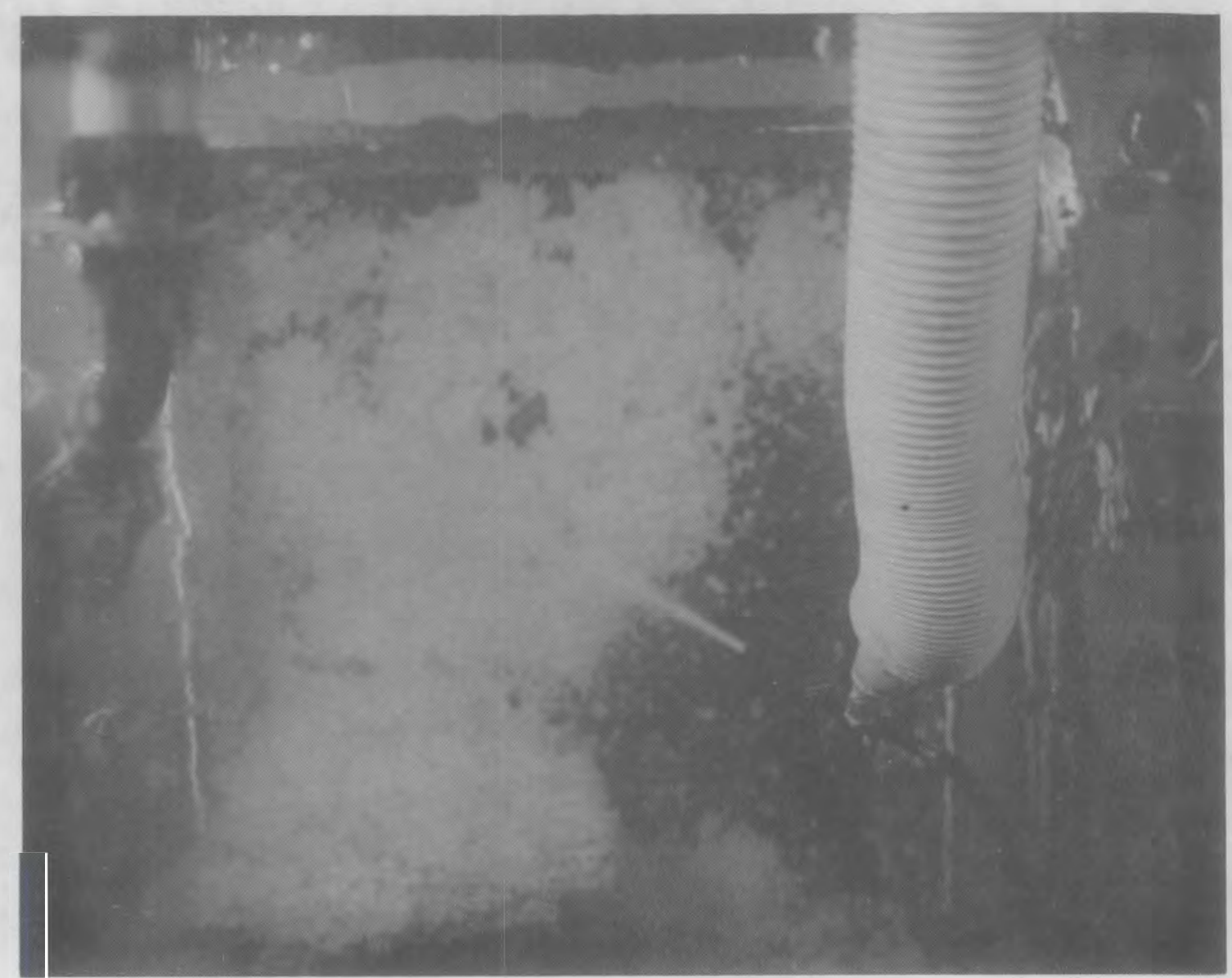

$88101222-10 \mathrm{CN}$

FIGURE 4. Alkaline Foam Being Sprayed onto C-Ce11 Wall

(a) ARO Corporation, One ARO Center, Bryan, Ohio.

(b) DuBois Chemical is a division of Chemed Corporation, Cincinnati, Ohio. 
The pressurized water system consists of a high-pressure plunger pump that is belt-driven with a 15-hp electric motor. Water pressure available to the spray nozzle may be set by adjustments to a regulating unloader valve. In the decontamination of $\mathrm{C}$-Cell, the pressure unloader was set at $5000 \mathrm{psig}$ to give a water flow rate of about $1.6 \mathrm{gpm}$ through a spray nozzle having a 0.031-in.-dia. tungsten carbide orifice. Figure 5 shows the foam, after soaking for about $30 \mathrm{~min}$., being spray-washed from the C-Cell wa11. Figure 6 shows an extended articulated spray wand, suspended from the cell crane hook,

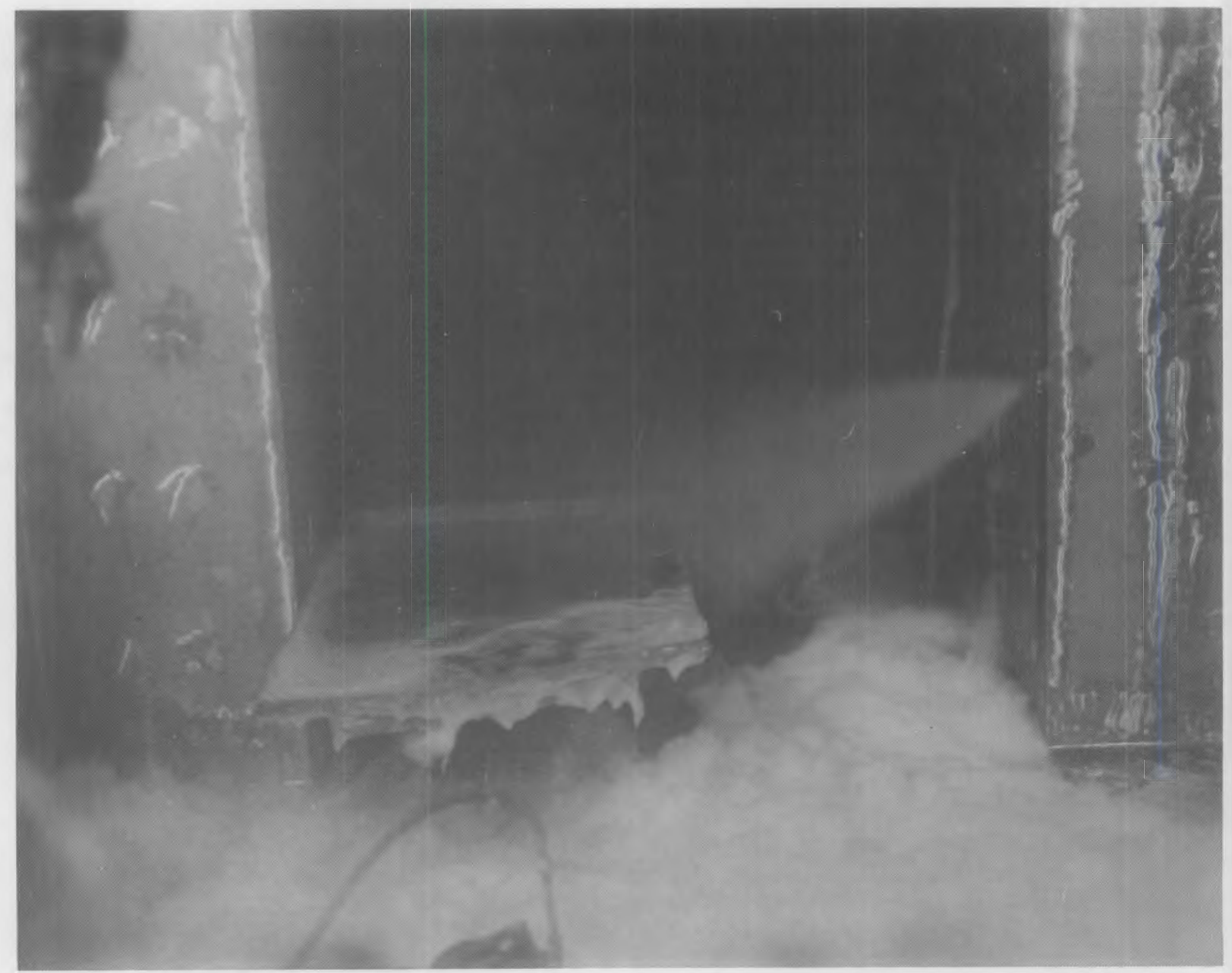

$88101222-19 \mathrm{CN}$

FIGURE 5. Alkaline Foam, After About a 30-min. Soak, Being Washed from C-Ce11 Wall with Pressurized Water 


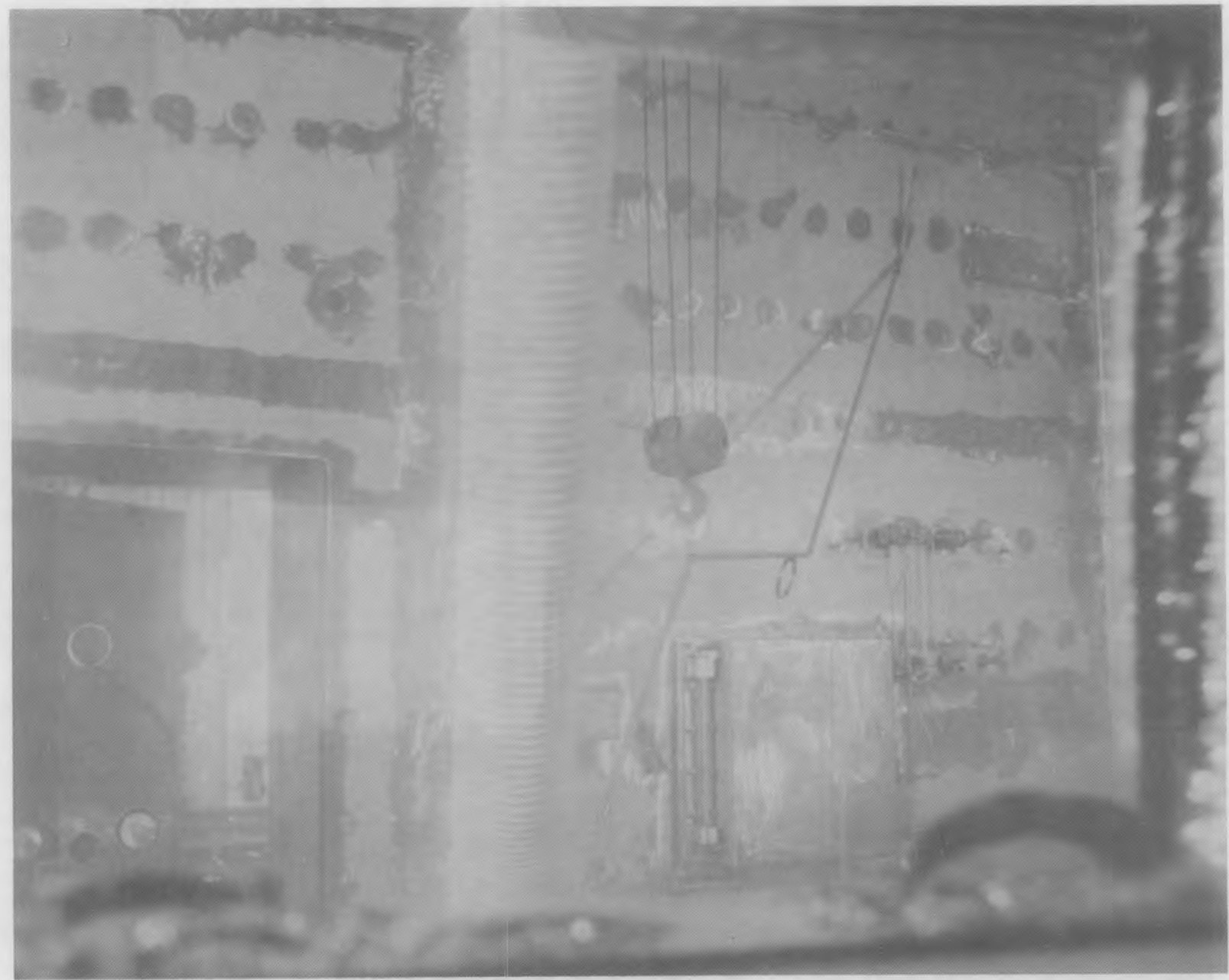

89011936-8CN

FIGURE 6. Articulated Spray Wand Suspended on Cell Crane

for washing the foam from the ceiling and from a ledge that encircles the placement of the cleaning wand nozzle, a remotely operated Rees Instruments CCTV camera with a 30 - to $150-\mathrm{mm}$ nonbrowning motorized zoom lens mounted atop a motorized pan and tilt unit was used. Figure 7 shows a view, photographed with the aid of a through-the-wall periscope, of the in-cell trough containing debris deposited during the first cleaning cycle. This material was removed with a remote vacuum cleaner prior to the second decontamination cycle. 


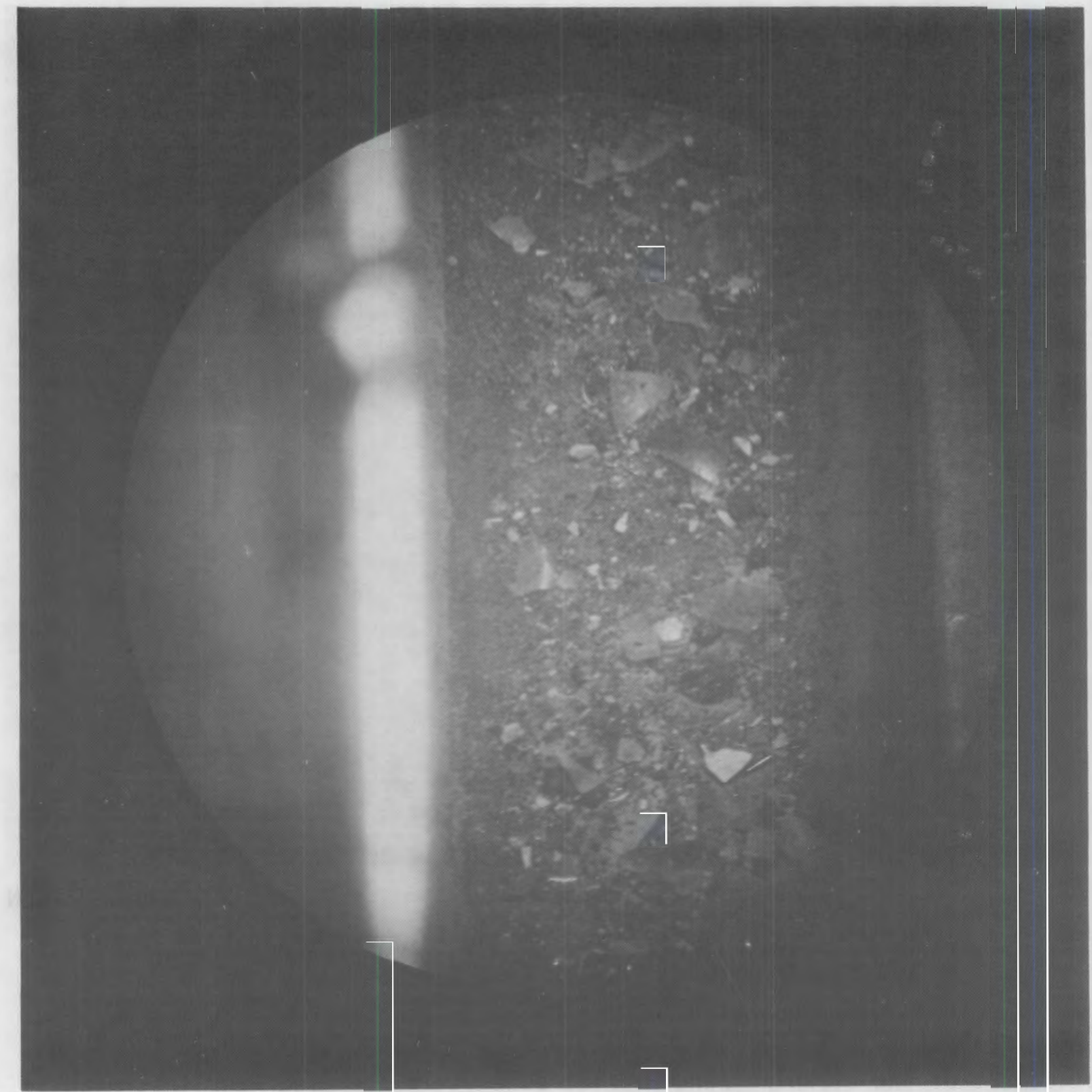

88101935-3CN

FIGURE 7. View Through C-Cell Viewing Periscope Showing Debris Washed to Trough During First Decontamination Cycle 
The radiation level of the cell surface was measured after each decontamination cycle. The remote radiation detection system previously described was used, and progress was monitored employing the same 6 by 8 cell matrix plus six additional areas. These latter areas represented the wall, the top of the exhaust filter, and the top of the electrical wiring tray for both the east and west cell walls. The average radiation exposure for the 54 selected areas calculated for each decontamination cycle is as follows:

$\begin{array}{lc}\text { Start } & 21.0 \mathrm{rad} / \mathrm{hr} \\ \text { First cycle } & 5.9 \mathrm{rad} / \mathrm{hr} \\ \text { Second cycle } & \text { (no measurement made) } \\ \text { Third cycle } & 1.4 \mathrm{rad} / \mathrm{hr} \\ \text { Fourth cycle } & 1.1 \mathrm{rad} / \mathrm{hr} \\ \text { Fifth cycle } & 0.6 \mathrm{rad} / \mathrm{hr} \\ \text { Sixth cycle } & 0.6 \mathrm{rad} / \mathrm{hr} .\end{array}$

Although the effectiveness of the decontamination to the fifth cycle is apparent, the sixth cycle does not appear to have helped lower overal1 radiation exposure in the cell. Likewise the redistribution of radioactivity observed between the decontamination cycles is not reflected in these averaged numbers.

Table 3 lists the radiation survey data and calculated decontamination factors (DF) for the six decontamination cycles. Figure 8 serves as a key to Table 3, locating the measured areas by their numerical designations. The increases and decreases in the radiation rates are random in location and in cycle number. Radioactivity from the walls and ceiling was observed to recontaminate lower horizontal surfaces, and the movement of radioactivity along horizontal surfaces with a manipulator-held spray wand was not always predictable. The overa11 DFs for the six cycles ranged from 2.97 to 1000 , with the 2.97 vaiue representing the cell sump. The radiation rate at the sump surface was never lower than $23 \mathrm{rad} / \mathrm{hr}$ and is believed to indicate that radioactivity was trapped between the stainless steel sump 1 iner and the sump floor. The lack of starting radiation data for cell locations 49 through 54 may account for their lower overall DF values as they were calculated from measurements taken after the first cycle. The cell crane became marginally operative and was not used for remote radiation measurements after the 
IABLE 3. Radiation Data Taken During Preliminary Remote Decontamination of C-Cell, in rads/hr, and Calculated Decontamination Factors

\begin{tabular}{|c|c|c|c|c|c|c|c|c|c|c|c|c|}
\hline & & After & & After & & After & & After & & After & & Overall \\
\hline Location $^{(a)}$ & $\underline{\text { Start }}$ & 1 st Cycle & $\underline{D F}$ & 3rd cycle & DF & 4th Cycle & DF & 5th crcle & $\underline{D F}$ & 6th Cycle & DF & DF \\
\hline 01 & 2.6 & 2.4 & 1.08 & 4.6 & 0.52 & 0.6 & 7.67 & 0.4 & 1.50 & 0.5 & 0.80 & 5.20 \\
\hline 02 & 7.0 & 9.5 & 0.74 & 6.4 & 1.48 & 0.7 & 9.14 & NA & NA & & & \\
\hline 03 & 8.5 & 3.0 & 2.83 & 4.0 & 0.75 & 0.5 & 8.00 & 0.5 & 1.00 & 0.3 & 1.67 & 28.33 \\
\hline 04 & 2.5 & 2.6 & 0.96 & 2.8 & 0.93 & 0.5 & 5.60 & 0.3 & 1.67 & 0.2 & 1.50 & 12.50 \\
\hline 05 & 3.6 & 3.8 & 0.95 & 2.5 & 1.52 & 0.5 & 5.00 & 0.2 & 2.50 & 0.2 & 1.00 & 18.00 \\
\hline 06 & 4.6 & 3.9 & 1.18 & 2.5 & 1.56 & 0.5 & 5.00 & 0.2 & 2.50 & 0.2 & 1.00 & 23.00 \\
\hline 07 & 3.8 & 3.8 & 1.00 & 2.3 & 1.65 & 0.4 & 5.75 & 0.2 & 2.00 & 0.1 & 2.00 & 38.00 \\
\hline $0 B$ & 3.9 & 3.0 & 1.30 & 2.4 & 1.25 & 0.5 & 4.80 & 0.2 & 2.50 & 0.1 & 2.00 & 39.00 \\
\hline 09 & 5.0 & 4.8 & 1.04 & 2.6 & 1.85 & 0.5 & 5.20 & 0.9 & 0.56 & 0.1 & 9.00 & 50.00 \\
\hline 10 & 4.0 & 5.2 & 0.77 & 2.4 & 2.17 & 0.5 & 4.80 & 0.2 & 2.50 & 0.1 & 2.00 & 40.00 \\
\hline 11 & 7.0 & 8.0 & 0.88 & 2.6 & 3.08 & 0.5 & 5.20 & 0.2 & 2.50 & 0.1 & 2.00 & 70.00 \\
\hline 12 & 8.0 & 6.0 & 1.33 & 2.6 & 2.31 & 0.5 & 5.20 & 0.2 & 2.50 & 0.2 & 1.00 & 40.00 \\
\hline 13 & 8.0 & 5.0 & 1.60 & 2.8 & 2.86 & 0.5 & 16.00 & 0.4 & 1.25 & 0.2 & 2.00 & 40.00 \\
\hline 14 & 6.0 & 4.5 & 1.33 & 3.7 & 1.22 & 0.6 & 6.17 & 0.7 & 0.86 & 0.3 & 2.33 & 20.00 \\
\hline 15 & 18.4 & 12.0 & 1.53 & 3.0 & 4.00 & 0.6 & 5.00 & 0.4 & 1.50 & 0.5 & 0.80 & 36.80 \\
\hline 16 & 3.8 & 3.2 & 1.18 & 3.4 & 0.94 & 0.6 & 5.67 & 0.4 & 1.50 & 0.4 & 1.00 & 9.50 \\
\hline 17 & 8.0 & 7.5 & 1.07 & 3.4 & 2.21 & 0.7 & 4.86 & 0.4 & 1.75 & 0.4 & 1.00 & 20.00 \\
\hline 18 & 15.0 & 12.5 & 1.20 & 3.0 & 4.17 & 0.7 & 4.29 & 0.7 & 1.00 & 0.4 & 1.75 & 37.50 \\
\hline 19 & 11.0 & 22.0 & 0.50 & 3.1 & 7.10 & 0.6 & 5.17 & 1.3 & 0.46 & 0.3 & 4.33 & 36.67 \\
\hline 20 & 6.3 & 5.0 & 1.25 & 3.7 & 1.35 & 0.5 & 7.40 & 0.3 & 1.67 & 0.2 & 1.50 & 31.50 \\
\hline 21 & 15.0 & 45.0 & 0.33 & 2.5 & 18.00 & 0.5 & 5.00 & 0.2 & 2.50 & 0.2 & 1.00 & 75.00 \\
\hline 22 & 17.0 & 10.0 & 1.70 & 2.6 & 3.85 & 0.5 & 5.20 & 0.2 & 2.50 & 0.1 & 2.00 & 17.00 \\
\hline 23 & 8.2 & 5.7 & 1.44 & 2.5 & 2.28 & 0.5 & 5.00 & 0.2 & 2.50 & 0.2 & 1.00 & 41.00 \\
\hline 24 & 7.9 & 5.8 & 1.36 & 2.8 & 2.07 & 0.5 & 5.60 & 0.4 & 1.25 & 0.1 & 4.00 & 79.00 \\
\hline 25 & 19.0 & 18.0 & 1.06 & 3.0 & 6.00 & 0.6 & 5.00 & 0.3 & 2.00 & 0.1 & 3.00 & 190.00 \\
\hline 26 & 18.0 & 11.0 & 1.64 & 2.5 & 4.40 & 0.5 & 5.00 & 0.2 & 2.50 & 0.2 & 1.00 & 90.00 \\
\hline 27 & 15.0 & 15.0 & 1.00 & 2.8 & 5.36 & 0.6 & 4.67 & 0.2 & 3.00 & 0.2 & 1.00 & 75.00 \\
\hline 28 & 46.0 & 34.0 & 1.35 & 3.0 & 11.33 & 0.6 & 5.00 & 0.3 & 2.00 & 0.2 & 1.50 & 230.00 \\
\hline
\end{tabular}


TABLE 3. Cont'd.

\begin{tabular}{|c|c|c|c|c|c|c|c|c|c|c|c|c|}
\hline & & After & & After & & After & & After & & After & & Overall \\
\hline Location ${ }^{(a)}$ & start & 1st Crcle & DF & 3 rd Cycle & of & 4th cycle & DF & 5th cycle & DF & 6th Cycle & $\underline{D F}$ & DF \\
\hline 29 & 9.0 & 18.0 & 0.50 & 2.9 & 6.31 & 0.6 & 4.83 & 0.4 & 1.50 & 0.2 & 2.00 & 45.00 \\
\hline 30 & 20.0 & 15.0 & 1.33 & 3.3 & 4.55 & 0.6 & 5.50 & 2.0 & 0.30 & 0.3 & 6.67 & 66.67 \\
\hline 31 & 45.0 & 14.0 & 3.21 & 5.0 & 2.80 & 1.3 & 3.85 & 1.6 & 0.81 & 1.3 & 1.23 & 34.62 \\
\hline 32 & 21.6 & 60.0 & 0.36 & 5.8 & 10.34 & 2.3 & 2.52 & 1.0 & 2.30 & 0.8 & 1.25 & 27.00 \\
\hline 33 & 40.8 & 11.0 & 3.71 & 9.6 & 1.15 & 3.0 & 3.20 & 2.7 & 1.11 & 3.6 & 0.75 & 11.33 \\
\hline 34 & 200.0 & 55.0 & 3.64 & 19.0 & 2.89 & 5.2 & 3.65 & 3.8 & 1.37 & 3.8 & 1.00 & 52.63 \\
\hline 35 & 200.0 & 30.0 & 6.67 & 3.7 & 8.11 & 1.1 & 3.36 & 1.5 & 0.73 & 0.3 & 5.00 & 666.67 \\
\hline 36 & 16.0 & 13.0 & 1.23 & 4.2 & 3.10 & 1.3 & 3.23 & 0.5 & 2.60 & 0.3 & 1.67 & 53.33 \\
\hline 37 & 10.0 & 17.5 & 0.57 & 8.3 & 2.11 & 1.2 & 6.92 & 0.5 & 2.40 & 0.6 & 0.83 & 16.67 \\
\hline 38 & 40.0 & 25.0 & 1.60 & 3.2 & 7.81 & 1.1 & 2.91 & 0.3 & 3.67 & 0.2 & 1.50 & 200.00 \\
\hline 39 & 200.0 & 55.0 & 3.64 & 3.2 & 17.19 & 1.0 & 3.20 & 0.4 & 2.50 & 0.2 & 2.00 & 1000.00 \\
\hline 40 & 20.0 & 9.0 & 2.22 & 5.5 & 1.64 & 1.8 & 3.06 & 0.5 & 3.60 & 0.2 & 2.50 & 100.00 \\
\hline 41 & 18.0 & 16.0 & 1.13 & 12.0 & 1.33 & 3.6 & 3.33 & 0.2 & 18.00 & 0.5 & 0.40 & 36.00 \\
\hline 42 & 50.0 & 12.4 & 4.03 & 5.5 & 2.25 & 1.2 & 4.58 & 0.9 & 1.33 & 0.6 & 1.50 & 83.33 \\
\hline 43 & 22.0 & 23.0 & 0.96 & 4.6 & 5.00 & 1.0 & 4.60 & 0.4 & 2.50 & 0.5 & 0.80 & 44.00 \\
\hline 44 & 23.0 & 30.0 & 0.77 & 5.8 & 5.17 & 1.5 & 3.87 & 0.6 & 2.50 & 0.5 & 1.20 & 46.00 \\
\hline 45 & 42.0 & 38.0 & 1.11 & 5.8 & 6.55 & 1.8 & 3.22 & 1.2 & 1.57 & 0.5 & 2.40 & 84.00 \\
\hline 46 & 200.0 & $\pi 5.0$ & 2.67 & 12.0 & 6.25 & 3.2 & 3.75 & 1.6 & 2.00 & 0.5 & 3.20 & 400.00 \\
\hline 47 & 200.0 & 150.0 & 1.33 & 35.0 & 4.29 & 10.0 & 3.50 & 4.6 & 2.17 & 2.8 & 1.64 & 71.43 \\
\hline 48 & 85.0 & 28.0 & 3.04 & 46.0 & 0.61 & 23.0 & 2.00 & 24.3 & 0.95 & 28.6 & 0.85 & 2.97 \\
\hline 49 & NA & 13.7 & & 14.2 & 0.96 & 6.7 & 2.12 & 6.5 & 1.03 & 2.5 & 2.60 & 5.48 \\
\hline 50 & NA & 10.7 & & 3.7 & 2.89 & 2.7 & 1.37 & 3.0 & 0.90 & 1.6 & 1.88 & 6.69 \\
\hline 51 & NA & 2.9 & & 4.8 & 0.60 & 0.8 & 6.00 & 1.0 & 0.80 & 0.4 & 2.50 & 7.52 \\
\hline 52 & NA & 2.0 & & 5.9 & 0.34 & 0.8 & 7.38 & 0.3 & 2.67 & 0.4 & 0.75 & 5.00 \\
\hline 53 & NA & 5.5 & & 7.4 & 0.74 & 1.2 & 6.17 & 0.8 & 1.50 & 1.5 & 0.53 & 3.67 \\
\hline 54 & NA & 7.8 & & 8.6 & 0.91 & 1.2 & 7.17 & 0.9 & 1.33 & 0.5 & 1.80 & 15.60 \\
\hline
\end{tabular}

(a) For in-cell location of radiation measurement see figure 8. 


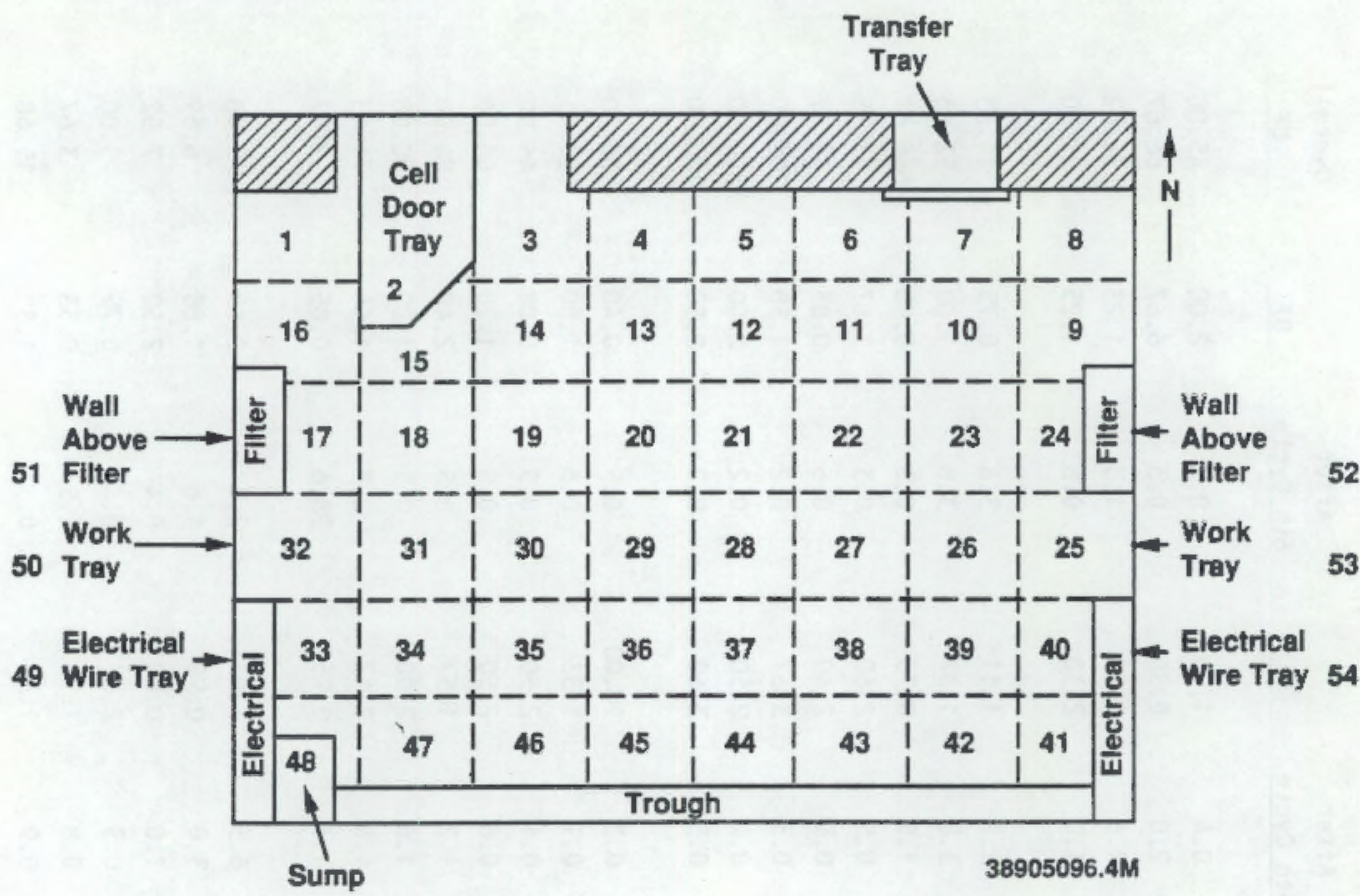

FIGURE 8. Numerical Designations, as used in Table 3, for Areas in the $6 \times 8$ Radiation Survey Matrix and for the Six Additional Remotely Surveyed Areas

seventh decontamination cycle. On completion of the preliminary decontamination phase totalling eight cycles, the radiation level within C-Cell measured between 150 and $200 \mathrm{mrad} / \mathrm{hr}$ for most of the cell. The exception was a higher radiation level immediately atop the cell sump. Here radioactivity is suspected to have seeped under the stainless steel liner through a liner breach that is yet to be located. A semiremote dye-penetrant test of the sump liner showed no macroscopically obvious cracks in the liner although many signs of pitting were present. A radiation shielding cover of stainless steel and lead was placed over the sump during the first manned entry into C-Cell.

\section{FINAL DECONTAMINATION}

An ultra high-pressure water decontamination system manufactured by Admac, Inc. was used for the final decontamination. A diesel-powered Jetpac ultra high-pressure pump system, with four parallel, hydraulically driven, 
double-acting fluid intensifiers, was used to feed a Model 5050 MKII-A Jetlance $^{\mathrm{N}}$ system. The hand-held Jetlance had a hydraulic motor-driven, highspeed rotary spray head containing eight fluid jet nozzles with 0.008 -in.-dia orifices.

For ALARA purposes, a 36-in. stem set was used to maximize the distance between the technician and the surfaces being cleaned. A hands-on training session, held in a nonradioactive area and prerequisite for in-cell qualification, allowed each technician to become familiar with the operational features of the Jetlance. Figure 9 shows the Jetlance with the $3-\mathrm{ft}$ extension being used during the training session. Potential hazards from improper handling of the Jetlance were demonstrated by spray-damaging samples of in-cell protective apparel and equipment such as shown in Figure 10.

For the final decontamination, the technicians wore water-shedding plastic sheeting taped over the normal paper-based hood and a fresh airsupplied mask. Figure 11 shows a technician as the water is turned on to the Jetlance. The technicians had their individual ways to handle the thrust from the water jets; some would rock back as the water was turned on and then move the nozzle to the effective working distance of 1 in., and others would start with the nozzles close to the wall. Figure 12 is a typical view of the activated Jetlance at the normal decontamination distance from the work surface.

For safety, only the Jetlance operator was allowed in $\mathrm{C}$-Cell during decontamination. The observer was stationed at the C-Cell viewing windows, with visual communication to the in-cell operator and vocal communication to the air lock door attendant. The wash water was seen to contain dark particulates when the ledge that encircled the cell at the $12-\mathrm{ft}$ level was being cleaned with the Jetlance. The stainless steel wall liner was observed to become shinier as the Jetlance was passed over its surface.

MA trademark of Admac, Inc., Kent, Washington. 


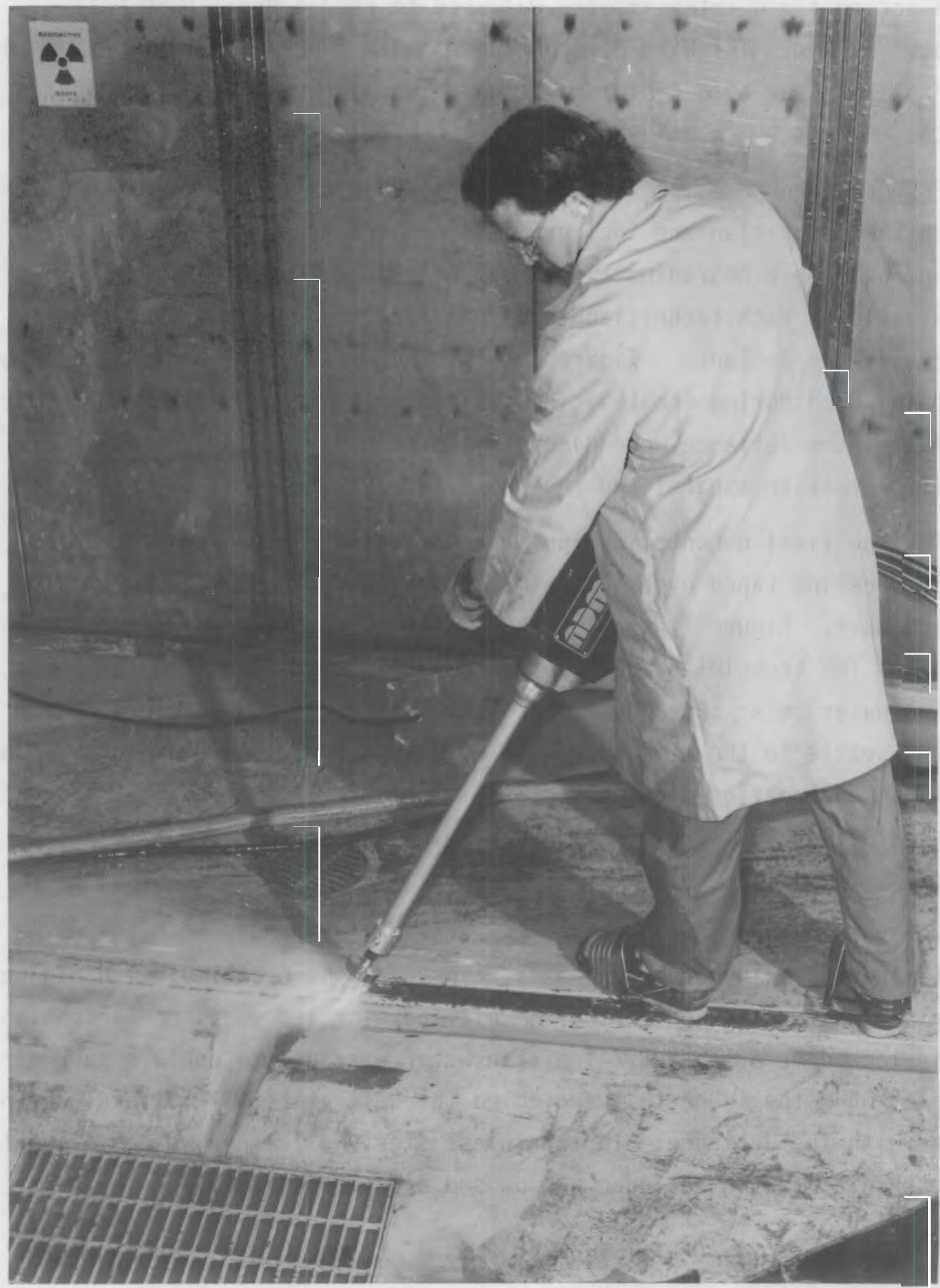

$89020720-23 \mathrm{CN}$

FIGURE 9. Training Session on Use of Admac Jetlance with 36-in. Extension 


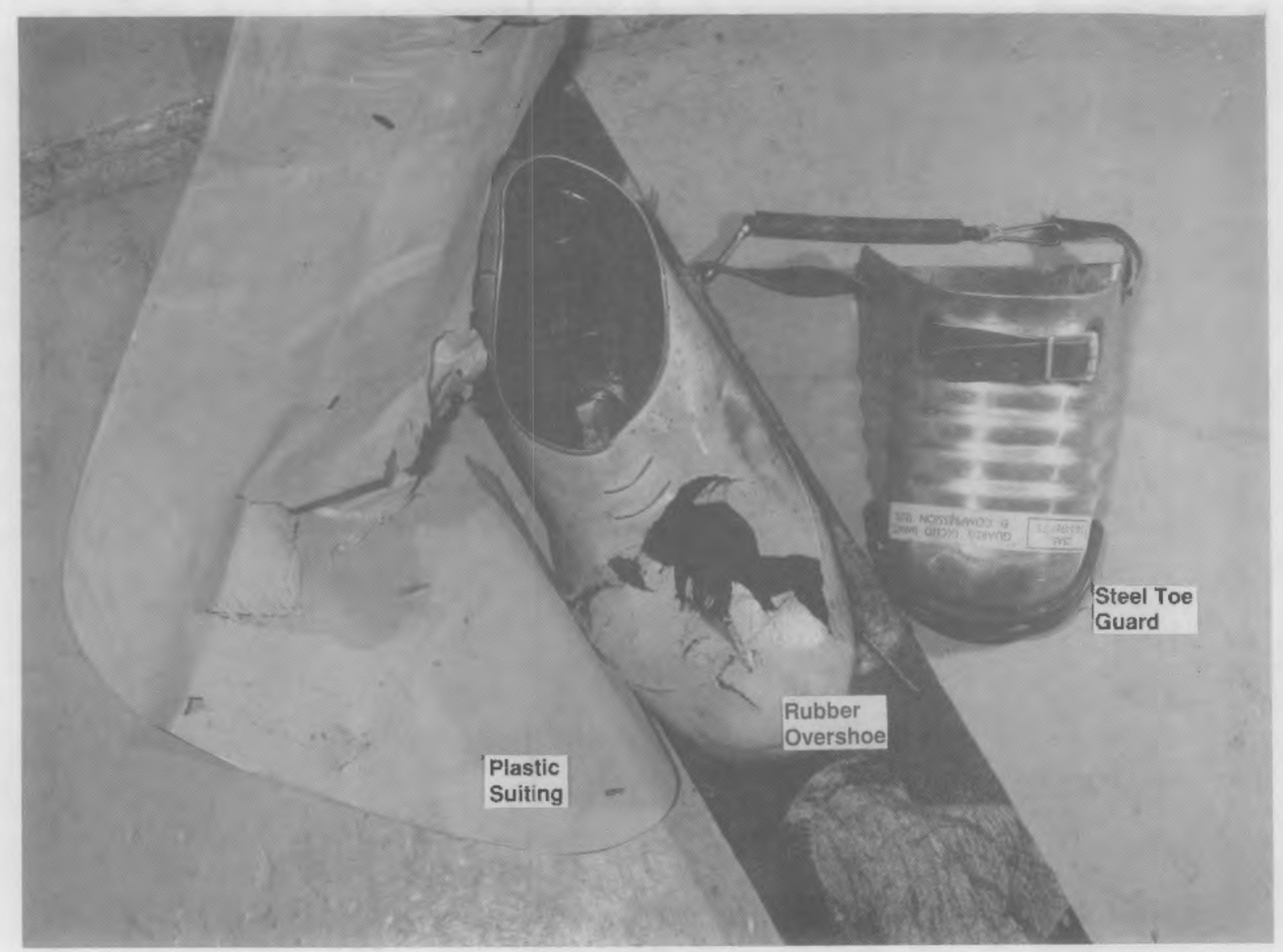

$89020720-26 \mathrm{CN}$

FIGURE 10. Demonstration of Potential Hazards Resulting from Careless Use of Jetlance

It was fatiguing to use the $28-1 b$ Jetlance, with its heavy trailing water and hydraulic hoses, on the ceiling and elevated wall areas (Figure 13), where the actual cleaning times ranged from 10 to about 30 min. To decrease the effect of the water thrust, nozzle pressure was lowered to about 26,000 psig for the ceiling and elevated wall areas. The lower walls and floor were done at about 39,000 psig water pressure, and cleaning times increased to range from 20 to $40 \mathrm{~min}$. 


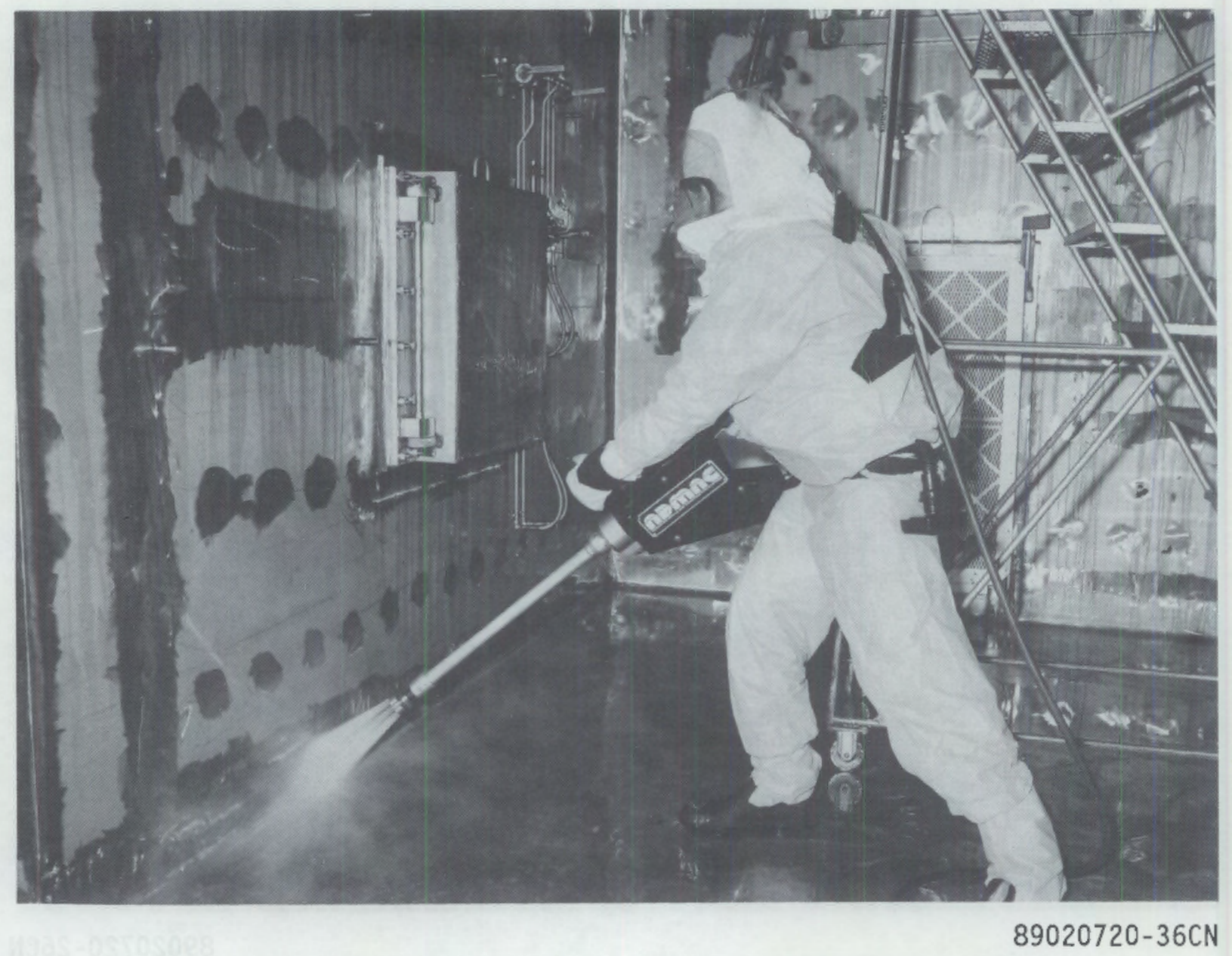

FIGURE 11. View of Operation When U1tra High-Pressure Water Is Initially Turned On in Jetlance 


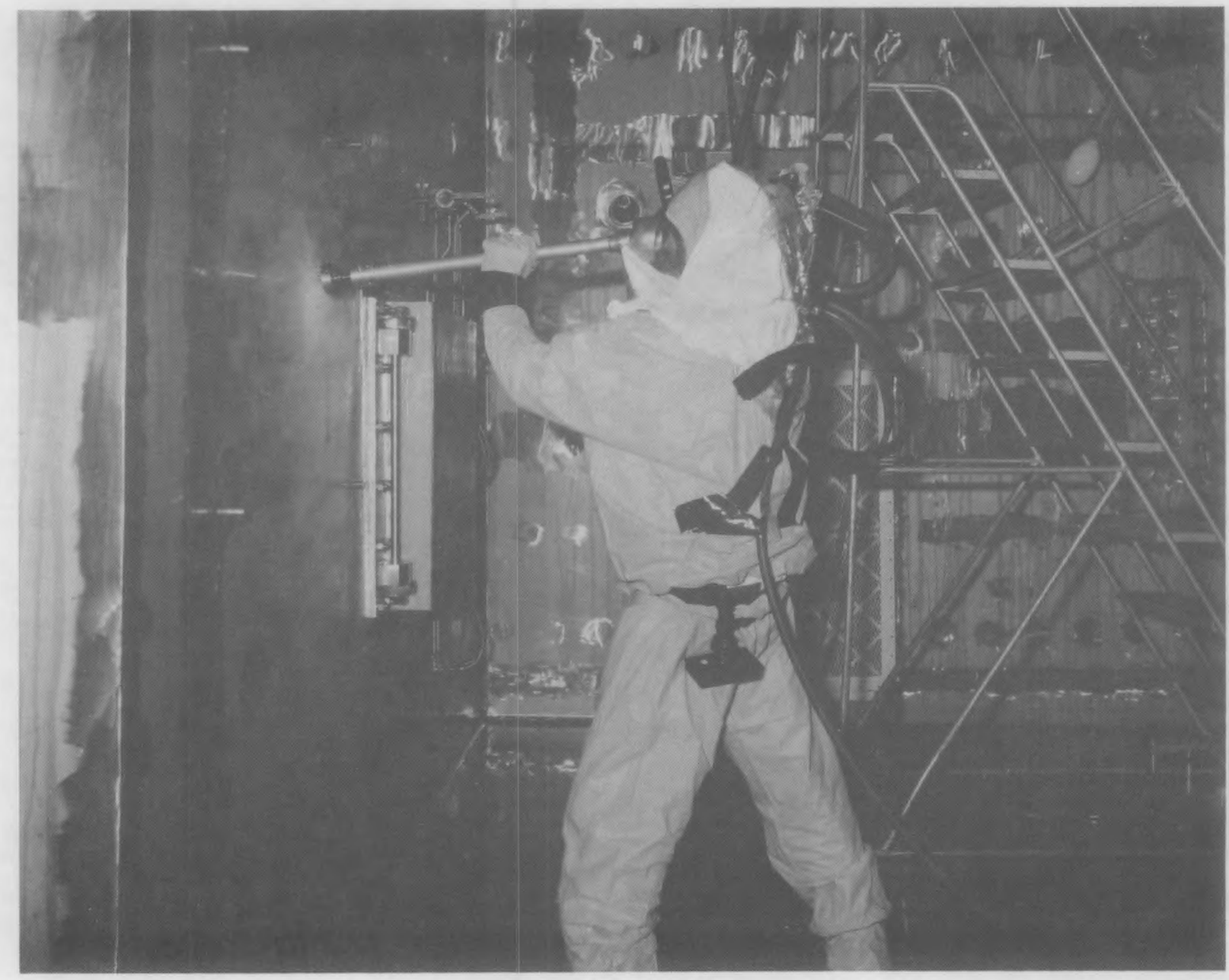

$89020720-40 \mathrm{CN}$

FIGURE 12. Typical Distance Between Jetlance and Surface During Decontamination 


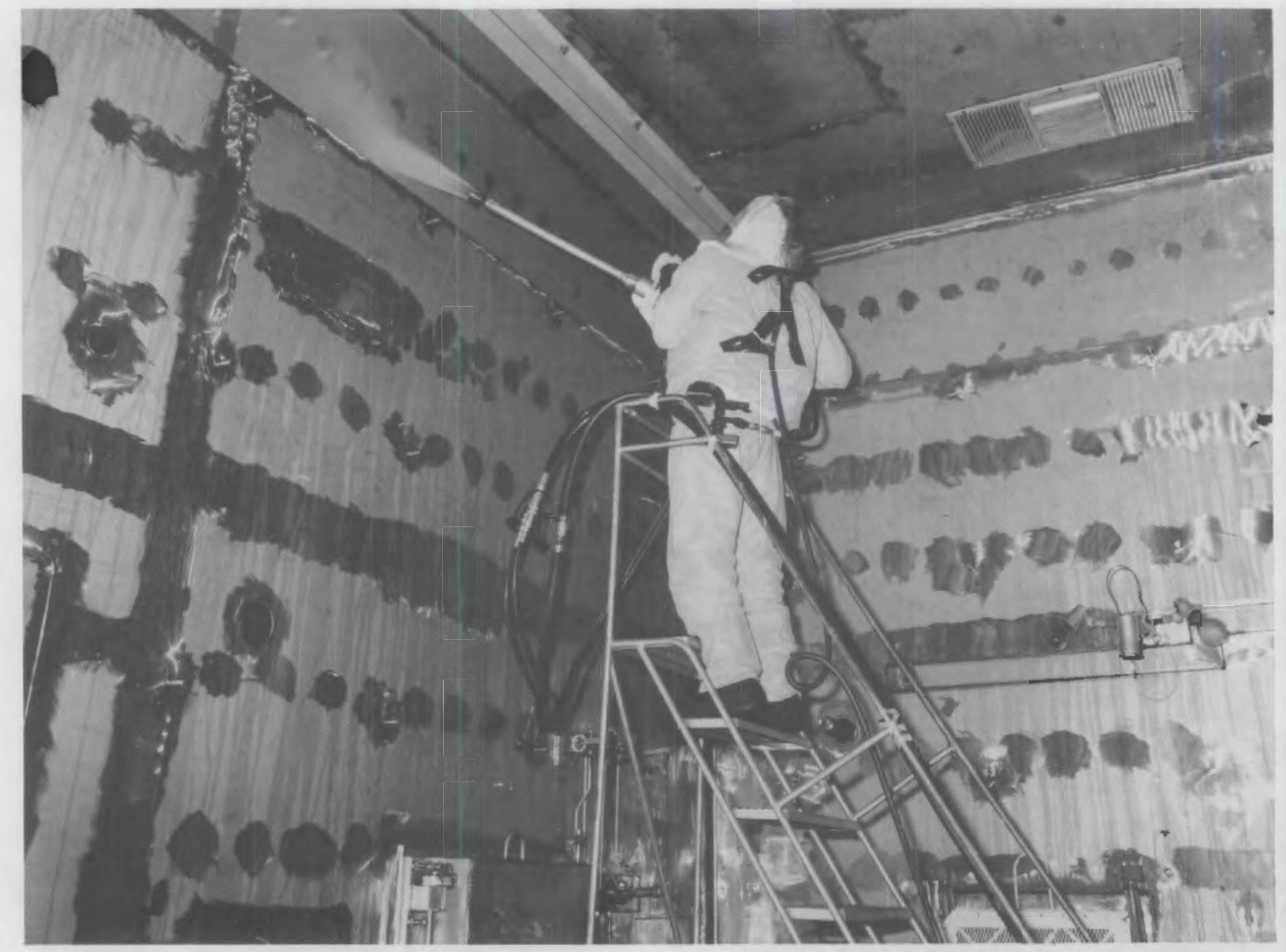

$89020720-31 \mathrm{CN}$

FIGURE 13. Physical Conditions for Elevated Hand-Held Jetlance Operation 


\section{POST-DECONTAMINATION ANALYSES}

The final radiation dose measurements and smear samples were taken on typical areas of cell surface distributed as shown in Figure 14. Squares of $100 \mathrm{~cm}^{2}$ were marked on the surfaces, and direct radiation readings with a black widow CP and smear samples were both taken for each area. These smear samples were packaged and removed from the cell for radioactivity measurements with a pancake-probed Geiger-Müller counter. Table 4 shows the radiation data from the final radiation survey of C-Cell. The smear sample from position 13, where a temporary sump pump was located, measured off scale, $>100,000$ counts per minute, with the pancake-probed GM, and $13 \mathrm{mrad} / \mathrm{hr}$ with a $C P$. This smear sample contained macroscopically visible particulates. The remaining 12 smear samples averaged 11,800 counts $/ \mathrm{min} / 100 \mathrm{~cm}^{2}$, which corresponds to about $1 \mathrm{mrad} / \mathrm{hr} / 100 \mathrm{~cm}^{2}$. Direct radiation measurements of the same 12 areas before smear sampling averaged $149 \mathrm{mrad} / \mathrm{hr}$ and $97.5 \mathrm{mR} / \mathrm{hr}$.

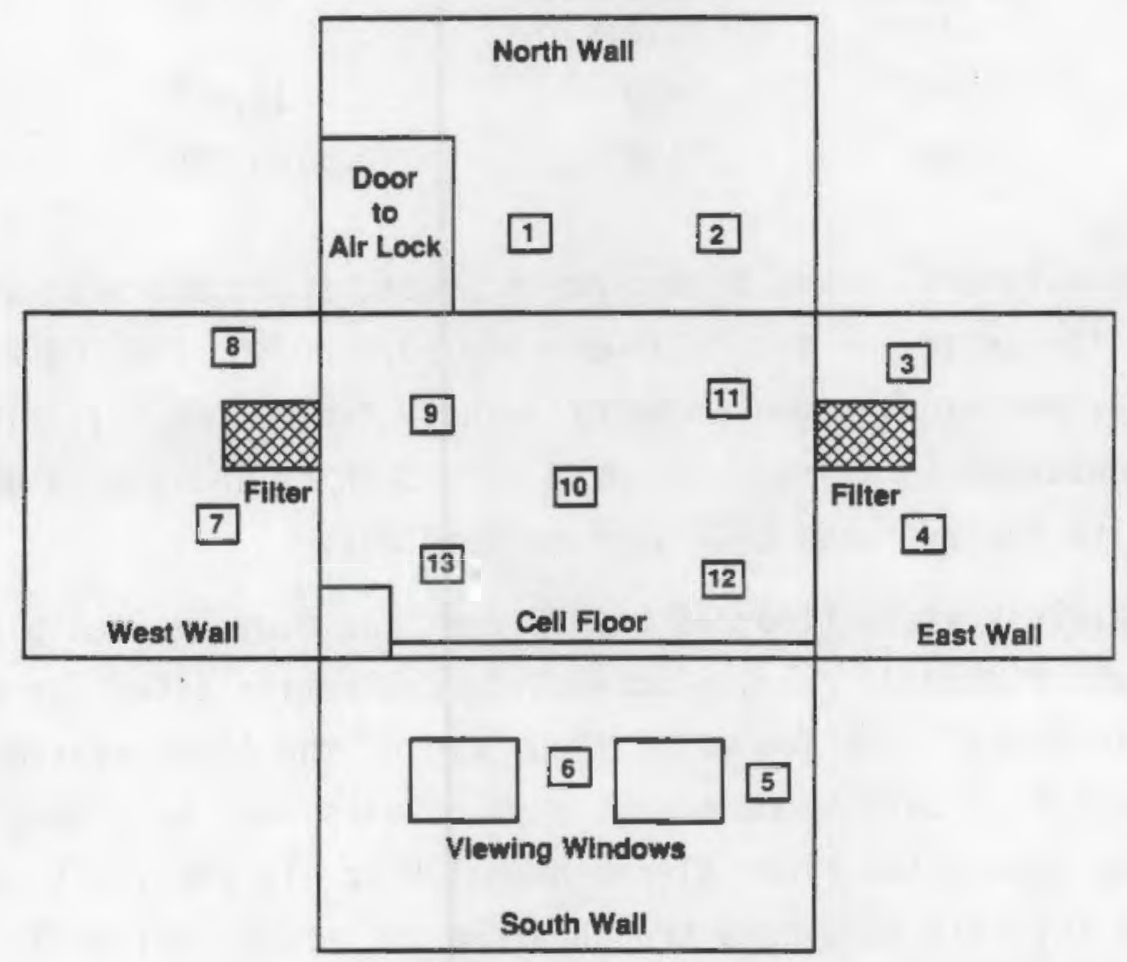

38905096.1

FIGURE 14. Locations of Final Radiation Survey in C-Cell Shown on a Floor and Wall Layout Sketch 
TABLE 4. Final Radiation Survey Measurements in C-Ce11. Direct surface readings were taken with a black widow $C P$, and $100-\mathrm{cm}^{2}$ smearsample readings were made with a pancake-probed GM and a CP.

\begin{tabular}{|c|c|c|c|c|}
\hline \multirow[b]{2}{*}{ Location } & \multicolumn{2}{|c|}{ Direct Reading } & \multicolumn{2}{|c|}{ Smear Samples } \\
\hline & $\begin{array}{r}\text { B1ack } \\
\mathrm{mrad} / \mathrm{hr}\end{array}$ & $\begin{array}{c}\text { dow CP } \\
\mathrm{mR} / \mathrm{hr}\end{array}$ & $\begin{array}{c}\text { GM } \\
\text { counts/min }\end{array}$ & $\begin{array}{c}\mathrm{CP} \\
\mathrm{mrad} / \mathrm{hr}\end{array}$ \\
\hline 1 & 50 & 50 & 10,000 & 1 \\
\hline 2 & 40 & 40 & 4,500 & \\
\hline 3 & 40 & 40 & 3,000 & \\
\hline 4 & 100 & 100 & 2,000 & \\
\hline 5 & 110 & 110 & 15,000 & \\
\hline 6 & 120 & 120 & 25,000 & 2 \\
\hline 7 & 110 & 110 & 15,000 & \\
\hline 8 & 80 & 80 & 8,000 & \\
\hline 9 & 100 & 80 & 20,000 & \\
\hline 10 & 40 & 40 & 14,000 & \\
\hline 11 & $\begin{array}{c}<\text { Detectible } \\
\text { Limit }\end{array}$ & $\begin{array}{c}<\text { Detectible } \\
\text { Limit }\end{array}$ & 10,000 & \\
\hline 12 & 1,000 & 400 & 15,000 & \\
\hline 13 & 1,000 & 400 & $>100,000$ & 13 \\
\hline
\end{tabular}

Radiation measurements taken facing north, east, south and west while standing in the center of the cell were 100/50,120/80,150/100 and 120/80, respectively, for window open $(\mathrm{mrad} / \mathrm{hr}) /$ window closed $(\mathrm{mR} / \mathrm{hr})$. These compass direction measurements average $122 \mathrm{mrad}$ and $78 \mathrm{mR} / \mathrm{hr}$ and are in good agreement with the averaged cell surface readings.

The stainless steel floor of C-Cell contains many surface pits and scratches, which provide readily accessible collection sites for contamination particulates. The low water flow rate of the Admac system, about $6 \mathrm{gpm}$, made it difficult to wash fine particulates over this rough surface to the sump even though the floor slopes down $1.5 \mathrm{in}$. in the $12 \mathrm{-ft}$ north-south direction of the cell towards a trough along the south cell wall. This fact is evident in the gradation of radiation rate measurements from the rear to 
the front of the cell, as shown in Figure 14. Some fine particulate material can be observed, with the aid of the periscope, on the front portions of the cell floor.

A total of 26 cell entries were made by hot-cell technicians, with an average Jetlance operating time of about 21 min per entry. The overall Jetlance cieaning rate for the $1592 \mathrm{ft}^{2}$ surface of the hot cell was $176 \mathrm{ft}^{2} / \mathrm{hr}$. Since about 20 additional minutes per entry is spent in putting on and removing the hot-cell protective apparel, considerable savings may be realized by extending the use time of the Jetlance per cell entry. Mast of the short-duration cell entries occurred in cleaning the ceiling and high elevations on the walls, where lifting the Jetlance and hoses (while holding the trigger-type on/off valve), coupled with the water jet thrust, was physically tiring. Future manned in-cell use of the Jetlance for decontaminating elevated surfaces will utilize a weight-supporting fixture and a nozzle-to-surface spacer.

A radiation dose of 2,626 mrem was accumulated during the 26 cell entries by hot-cell technicians and four cell entries by radiation protection technologists required to complete $C$-cell decontamination. This dose corresponds to $1.65 \mathrm{mrem} / \mathrm{ft}^{2}$ of surface decontamination. Thus the use of a remote predecontamination process and a final decontamination with ultra highpressure water reduced radiation dose by about $87 \%$ compared to the totally hands-on methods employed previously.

The decontamination cost was $\$ 153,000$, with technician labor costs being $68 \%$ of this total. This latter cost could have been reduced by improved methods for handling the Jetlance as described previously and by improved design of the remotely held spray wand used for the preliminary decontamination. The eight decontamination cycles used during the preliminary decontamination may be reduced to about four cycles with a properly designed spray wand. Based on the surface area of $\mathrm{c}-\mathrm{Cell}, 1,592 \mathrm{ft}^{2}$, the unit cost to decontaminate from $36,360 \mathrm{mrad} / \mathrm{hr}$ to $149 \mathrm{mrad} / \mathrm{hr}$ was $\$ 96 / \mathrm{ft}^{2}$. This cost is about $39 \%$ lower than the unit cost for surfaces cleaned previously using totally hands-on methods. 
A total of 1,476 gal of waste water, $0.93 \mathrm{gal} / \mathrm{ft}^{2}$, was generated during the decontamination and was transferred to a low-level waste treatment facility after sampling.

\section{CONCLUSIONS}

The 324 Building $\mathrm{C}-\mathrm{Ce} 11$, with a $1,592-\mathrm{ft}^{2}$ stainless steel lining, was decontaminated from an average of $36,360 \mathrm{mrad} / \mathrm{hr}$ to an average of $149 \mathrm{mrad} / \mathrm{hr}$. A remote predecontamination process was used followed by a final decontamination with ultra high-pressure water, yielding these results:

- Cost was $\$ 96 / \mathrm{ft}^{2}$.

- Radiation dose was $1.65 \mathrm{mrem} / \mathrm{ft}^{2}$.

- U1tra high-pressure water cleaning rate was $176 \mathrm{ft}^{2} / \mathrm{hr}$.

- Low-level waste water generation rate was $0.93 \mathrm{gal} / \mathrm{ft}^{2}$. 
PNL -6976

UC -511

\section{DISTRIBUTION}

No. of

Copies

OFFSITE

12 DOE/Office of Scientific and Technical Information

4 DOE Office of Civilian

Radioactive Waste Management Forrestal Building Washington, DC 20585

ATTN: L. H. Barrett, RW-33

S. H. Kale, RW-20

D. E. She]or, RW-32

R. Stein, RH-23

2 DOE Office of Defense Waste and GTN

Transportation Management

Washington, DC 20545

ATTN: K. A. Chacey, DP-123

T. B. Hindman, DP-12

4 DOE Office of Remedial Action GTN and Waste Technology

Washington, DC 20545

ATTN: J. E. Baublitz, NE-20

J. A. Coleman, NE-24

J. J. Fiore, NE-23

W. E. Murphie, NE-23

A. T. Clark

Division of Fuel Material

Safety

Nuclear Regulatory Commission

Washington, DC 20555

V. Stello

Office for the Executive

Director for Operations

Mail Station 17-G21

Nuclear Regulatory Commission

Washington, DC 20555
No. of

Copies

F. F. Gorup

Chicago Operations Office

U.S. Department of Energy

9800 S. Cass Avenue

Argonne, IL 60439

R. Grandfield

Dayton Area Office

U.S. Department of Energy

P.0. Box 66

Miamisburg, OH 45342

W. F. Holcomb

Environmental Protection Agency

Office of Radiation Programs (ANR-460)

401 M Street S.W.

Washington, DC 20460

P. A. Saxman

DOE ATbuquerque Operations Office

P.0. Box 5400

Albuquerque, NM 87185

W. McMullen

S. M. Stoller Corp.

4665 Indian School Rd. N.E. 104

A1buquerque, NM 87110-3930

E. Maestas

DOE West Valley Project

P.0. Box 191

West Valley, NY 14171

4 DOE Idaho Operations Office

785 DOE P1ace

Idaho Falls, ID 83402

ATTN: C. R. Enos

D. Majumdar

M. H. Shupe

J. E. Solecki 
No. of

Copies

2 DOE San Francisco Operations 1333 Broadway

0akland, CA 94612

ATTN: J. Ricks

S. Samuelson

M. R. Jugan

DOE Oak Ridge Operations Office P.0. Box E

Oak Ridge, TN 37830

2 DOE Savannah River Operations Office

P.0. Box A

Aiken, SC 29801

ATTN: $P$. Brandt

W. T. Goldston

J. J. Schreiber

Shippingport St. Decommissioning

U.S. Department of Energy

P.0. Box 335

Shippingport, PA 15077

L. Boing

Argonne National Laboratory

9700 South Cass Avenue

Argonne, IL 60439

C. S. Abrams

Argonne National Laboratory

P.0. Box 2528

Idaho Falls, ID 83401

3 Battelle Memorial Institute

Project Management Division

$505 \mathrm{King}$ Avenue

Columbus, $\mathrm{OH} 43201$

ATTN: W. A. Carbeiner

R. A. Nathan

Technical Library

B. J. Dionne

Brookhaven National Laboratory

Bldg. $703 \mathrm{M}$

Upton, Long Island, NY 11973
No. of

Copies

L. D. Ramspott

Lawrence Livermore National Laboratory

University of California

P.0. Box 808

Livermore, CA 94550

2 Los Alamos National Laboratory

P.0. Box 1663

Los Alamos, NM 87545

ATTN: D. T. Oakley, MS-J521

D. Padilla

3 P. T. Owen

Remedial Action Program Information Center

Oak Ridge Nationa] Laboratory

P.0. Box 2008, Bldg. 2001

Oak Ridge, TN 37831-6050

2 Sandia Laboratories

P.0. Box 5800

A1buquerque, NM 87185

ATTN: R. W. Lynch

Technical Library

M. Tucker

Grand Junction Project Office

Idaho Operations office

U.S. Department of Energy

785 DOE P1ace

ldaho Falls, ID 83042

J. R. Berreth

Westinghouse Idaho Nuclear

Co., Inc.

P.0. Box 4000

Idaho Falls, ID 83041

3 Westinghouse Savannah River Company

Savannah River Site

Aiken, SC 29B0l

ATTN: M. D. Boersma 77341A

J. R. Knight $773 \mathrm{~A}$

C. T. Randal] 7042 
No. of

Copies

R. G. Baxter

Westinghouse Savannah River Company

Savannah River Site

Bìdg. 704-S

Aiken, SC 29808-0001

A. D. Rodgers

Majl Stop 2411

EG\&G Idaho

P.0. Box 1625

Idaho Fal1s, ID 83415

R. Shaw

Electric Power Research Institute

3412 Hillview Avenue

P.0. Box 10412

Palo Alto, CA 94303

2 West Valley Nuclear Services Company

P.0. Box 191

West Valley, NY 14171

ATTN: R. E. Gessner

R. A. Thomas

2 Roy F. Weston, Inc.

office of Technical Services 20030 Sentry Boulevard, Suite 301

Germantown, MO 20874

ATTN: L. R. Lewis

T. A. Russell

J. L. White, Chairman

Energy Research \& Development

Authority

Empire State Plaza

Albany, NY 12223
No. of

Copies

ONSITE

8 DOE Richland Operations office

R. W. Brown

R. D. Freeberg

R. E. Gerton

J. Goodenough

R. A. Holten

J. C. Peschong

S. M. Prestwich

G. R. Yesberger

8 Westinghouse Hanford Company

J. S. Brehm

W. F. Heine

G. W. Jackson

R. L. Miller (3)

D. R. Speer

G. A. Tarcza

24 Pacific Northwest Laboratory

R. P. A11en

H. C. Burkholder

J. F. Dickman

J. E. Gose

F. E. Haun

G. R. Hoenes

L. K. Holton, Jr. (5)

Y. B. Katayama (5)

J. L. MCElroy

J. E. Surma

Publishing Coordination

Technical Report Files (5) 
• 